\title{
Scandinavistics by the Prominent Russian Historian Professor Vozgrin
}

\author{
V.N.Baryshnikov, V.N.Borisenko, V.N. Chepik, T. Plath
}

For citation: Baryshnikov V.N., Borisenko V.N., Chepik V.N., Plath T. Scandinavistics by the Prominent Russian Historian Professor Vozgrin. Vestnik of Saint Petersburg University. History, 2020, vol. 65, issue 3, pp. 990-1005. https://doi.org/10.21638/11701/spbu02.2020.318

The article describes the life path and analyzes academic achievements of a prominent Russian scholar, historian, member of the Danish Royal Academy of Sciences, professor of the Institute of History of St. Petersburg State University Valery Evgenyevich Vozgrin (1939-2020). The works of V. E. Vozgrin are well known in all Scandinavian countries, Germany, Italy, Spain, Estonia and other countries. The authors of the article highlight three main areas in his study of the history of the Scandinavian countries: first - the history of diplomacy and international relations of the $17^{\text {th }}$ and $18^{\text {th }}$ centuries, particularly, the diplomacy during the Great Northern War; second - the colonial policy of the countries such as Denmark and Sweden, which has never been researched by domestic historians; third - historiographic direction in the study of Scandinavian countries, which has never been developed on such a large scale in Russia before. Moreover, the analysis of a number of large historiographical works of the researcher clearly indicates an original style of the author in considering some little-known and very complex historiographic problems. The article concludes that the research base established by

Vladimir N.Baryshnikov - Doctor in History, Professor, St. Petersburg State University, 7-9, Universitetskaya nab., St. Petersburg, 199034, Russian Federation; v.baryshnikov@spbu.ru

Владимир Николаевич Барышников - д-р ист. наук, проф., Санкт-Петербургский государственный университет, Российская Федерация, 199034, Санкт-Петербург, Университетская наб., 7-9; v.baryshnikov@spbu.ru

Victor N.Borisenko - PhD in History, Associate Professor, St. Petersburg State University, 7-9, Universitetskaya nab., St. Petersburg, 199034, Russian Federation; v.borisenko@spbu.ru

Виктор Николаевич Борисенко - канд. ист. наук, доц., Санкт-Петербургский государственный университет, Российская Федерация, 199034, Санкт-Петербург, Университетская наб., 7-9; v.borisenko@spbu.ru

Victor N. Chepik - PhD in History, Senior Lecturer, St. Petersburg State University, 7-9, Universitetskaya nab., St. Petersburg, 199034, Russian Federation; v.chepik@spbu.ru

Виктор Николаевич Чепик - канд. ист. наук, ст. преп., Санкт-Петербургский государственный университет, Российская Федерация, 199034, Санкт-Петербург, Университетская наб., 7-9; v.chepik@spbu.ru

Tilman Plath - PhD, Researcher, Ernst Moritz Arndt University of Greifswald, 2, Rubenow str., Greifswald, 17487, Federal Republic of Germany; platht@uni-greifswald.de

Тильман Плат - PhD, науч. сотр., Грайфсвальдский университет им. Э.М. Арндта, Федеративная Республика Германия, 17487, Грайфсвальд, Рубенов штрассе, 2; platht@uni-greifswald.de

The reported study was funded by RFBR according to the research project No. 19-09-00383.

Исследование выполнено при финансовой поддержке РФФИ в рамках научного проекта № 19-09-00383.

() Санкт-Петербургский государственный университет, 2020 
professor Vozgrin for studying the history of the Scandinavian countries has laid a solid foundation for further examination of the history of the Nordic countries as well as for Scandinavistics in St. Petersburg to whose development V. Vozgrin made a considerable contribution.

Keywords: V. E. Vozgrin, history of Denmark, history of Sweden, Northern War, Scandinavistics, historiography of Scandinavian countries, colonial empires, diplomacy and international relations, historiography, $18^{\text {th }}$ century.

\title{
Скандинавские исследования выдающегося российского историка профессора Возгрина
}

\author{
В. Н. Барыиников, В. Н. Борисенко, В. Н. Чепик, Т. Плат
}

Для цитирования: Baryshnikov V.N., Borisenko V.N., Chepik V.N., Plath T. Scandinavistics by the Prominent Russian Historian Professor Vozgrin // Вестник Санкт-Петербургского университета. История. 2020. Т.65. Вып. 3. С. 990-1005. https://doi.org/10.21638/11701/spbu02.2020.318

В статье описывается жизненный путь, а также анализируются научные достижения выдающегося российского ученого, историка, члена Датской Королевской академии наук, профессора Института истории Санкт-Петербургского государственного университета Валерия Евгеньевича Возгрина (1939-2020). Работы В.Е. Возгрина хорошо известны во всех скандинавских странах, Германии, Италии, Испании, Эстонии и др. Авторы выделяют три основных направления в его исследовании истории Скандинавских стран. Во-первых, история дипломатии и международных отношений XVIIXVIII вв. и, прежде всего, скандинавского вектора европейской политики той эпохи. Анализ большого пласта работ В.Е.Возгрина, посвященных дипломатическому противостоянию периода Великой Северной войны, демонстрирует многогранность подхода историка к исследованию различных внешнеполитических проблем в целом. Во-вторых, колониальная политика Дании и Швеции. Она никогда ранее не изучалась отечественными историками. Работы В.Е. Возгрина свидетельствуют о комплексности проводившихся ученым исследований. В частности, им достаточно аргументированно раскрываются этапы становления и расширения колониальных империй, а также представлена специфика политики, отражающей эволюцию отношений между метрополией и колониями. В-третьих, источниковедческое и историографическое направление в изучении скандинавских стран никогда столь масштабно в России не разрабатывалось. Причем анализ ряда крупных историографических работ исследователя ясно указывает на особый авторский стиль ученого, который доступными для него средствами достаточно критически рассматривает отдельные малоизвестные и весьма сложные проблемы историографии. В статье утверждается, что созданная научно-исследовательская база по изучению истории Скандинавских стран является прочной основой для продолжения исследований истории стран Северной Европы и дальнейшего развития научной школы скандинавистики, в развитие которой в Санкт-Петербурге Валерий Евгеньевич Возгрин внес свой ощутимый вклад.

Ключевые слова: В.Е. Возгрин, история Дании, история Швеции, Северная война, скандинавизм, историография скандинавских стран, колониальные империи, дипломатия и международные отношения, историография, XVIII в.

A creative path of the outstanding Russian historian of Scandinavistics, a member of the Danish Royal Academy of Sciences, Professor Valerii Vozgrin generates genuine interest due to the diversity of his scholarly interests and very unusual changes in his personal 
biography. Moreover, his life path was not always characterized by inherent elements of a traditional armchair scientist.

Professor Vozgrin belonged to the pre-war generation of people whose fate in one way or another was determined by war. V.E. Vozgrin was born in Crimea in 1939 in the city of Simferopol in a family of school teachers. His father was a teacher of history, and his mother was a teacher of Russian language and literature. They worked together at the same school. Valery was the eldest of three brothers. Undoubtedly, during the Great Patriotic War, both he and his relatives were directly affected by the ordeals of that period. At the same time, professor V.E. Vozgrin had always displayed a lifelong love and devotion to his native land, where years of his childhood and youth passed. Subsequently, this was reflected in a number of fundamental works published both in Russia and abroad regarding the history of Crimea and the Crimean people ${ }^{1}$. The scholarly significance of these works is evidenced even by the fact that, characterizing them, a corresponding member of the Russian Academy of Sciences, Dr. R. S. Ganelin, described them "an outstanding phenomenon in historical science, not only Russian, but also world-wide"2.

But the main focus of the creative and academic activities of Professor V.E. Vozgrin was the study of the Nordic countries. Initially, it was difficult even to imagine that V.E. Vozgrin would choose for himself such a difficult path of researcher and historian. After graduating from high school, he entered the Evpatoria Maritime School, and then since 1957 he had served on the ships of the Black Sea Shipping Company for about five years. He was disciplined by the harsh naval environment there starting as an ordinary sailor and finishing his service as a pilot of one of the merchant sea ship. Sailing to distant countries of Southern and Western Europe, African countries as well as to the ports of Latin America, becoming familiar with the culture and life of countries far from the USSR, undoubtedly broadened his horizons.

In this respect, V.E. Vozgrin decided to continue his education choosing a humanitarian career completely unrelated to the service in the merchant fleet. He moved to Leningrad and, at the age of 23, in 1962, entered the Faculty of Philology at Leningrad State University. V.E. Vozgrin successfully passed difficult exams and entered a prestigious division of Scandinavian philology, the department of Danish language and literature, which was challenging. As a result, he began with diligence to study the extremely complex Danish language. Moreover, along with Danish V. E. Vozgrin also mastered German, Swedish, Norwegian, Icelandic, in addition to two "historical languages" such as Latin and Gothic. This linguistic diversity obviously predetermined Vozgrin's choice of that department. However, it was not enough for a young student, and Valery Evgenyevich began to learn the Dutch language.

Apparently, his passion for foreign languages encouraged him and aroused his interest in the history of the countries whose languages he actually studied. V. E. Vozgrin was lucky in that respect. At the time the largest scientific center for the study of history,

${ }^{1}$ See: Vozgrin V.E.: 1) Istoricheskie sud'by krymskikh tatar. Moscow, 1992; 2) Istoriia krymskikh tatar. Ocherki etnicheskoi istorii korennogo naseleniia Kryma v chetyrekh tomakh. Vol. 1-4. St. Petersburg, 2013; 3) Nemetskie kolonisty i korennoi narod Kryma v natsional'noi politike Rossiiskoii imperii. St. Petersburg, 2015; 4) Krymskie tatary v Otechestvennoi voine 1812 g. // Trudy kafedry istorii Novogo i noveishego vremeni. 2013. No. 10. P. 25; 5) Die Deportation der Krimtataren Gegen das Vergessen. Der Vernichtungskrieg gegen die Sowjetunion 1941-1945. Frankfurt am Main, 1992. P. 134.

${ }_{2}$ Ganelin R. Sh., Vozgrin V.E. Istoriia krymskikh tatar: ocherki etnicheskoi istorii korennogo naroda Kryma v chetyrekh tomakh // Trudy kafedry istorii Novogo i noveishego vremeni. 2014. No. 12. P. 252. 
languages and culture of Scandinavian countries and Finland was revived at Leningrad State University ${ }^{3}$. A new opportunity to attend additional lectures at the Faculty of History arose for students of the Faculty of Philology. Vozgrin's tutors at university were the founders and patriarchs of the national Scandinavistics, who had begun their schoraly work in the pre-war period. V.E. Vozgrin was schooled by such world-renowned professors as Doctor of Philological Sciences M. I. Steblin-Kamenskii ${ }^{4}$ and Doctor of Historical Sciences I. P. Shaskolskii ${ }^{5}$. Furthermore, under the supervision of professor I. P. Shaskolskii in 1967, Valery Evgenyevich wrote and successfully defended his thesis at the Faculty of History. What is more, his knowledge of foreign languages enabled him to prepare a very highly professional final research essay at the historical faculty. This, obviously, finally predetermined his future academic interests. He decided to devote himself to the research of Scandinavian history. Moreover, examination of Scandinavian sources, turned a young historian into a unique researcher for our country, because, to say the truth, the number of works on history of Denmark or, generally speaking - on the history of Russian-Danish relations, was very limited in the Russian historical sources and scholarship ${ }^{6}$. As a result, V.E. Vozgrin became a pioneer in this respect. It is no coincidence that after a short period at the Gipronickel Institute, where he was sent to work after graduation, he was employed at the Leningrad branch of the Institute of History of the USSR Academy of Sciences in 1970, where he began his $\mathrm{PhD}$ thesis?

The young researcher was immersed into thoughtful and very creative work. He had been writing his thesis for ten years. By this time his first scholarly papers had already been published. They clearly defined his research priorities. V.E. Vozgrin prepared a number of articles that dealt with issues of Russian-Danish relations on the eve and at the beginning of the Great Northern War, which had not been previously studied by Russian historians ${ }^{8}$. At the same time, he paid a lot of attention to working with sources and actively seeking to study historiographical problems ${ }^{9}$. It was the directions into which V.E. Vozgrin channelled his efforts later.

${ }^{3}$ Baryshnikov V.N., Daudov A. H. Izuchenie istorii stran Severnoi Evropy v Sankt-Peterburge (XVIIIXXI vv.) // Trudy kafedry istorii Novogo i noveishego vremeni. 2013. No. 11. P. 172.

${ }^{4}$ K semidesiatiletiiu so dnia rozhdeniia M. I. Steblin-Kamenskogo // Skandinavskii sbornik. Kn. XXIV. Tallinn, 1979. P. 5; M. I. Steblin-Kamenskii // Skandinavskii sbornik. Kn. XXIV. Tallinn, 1981. P.269; Mihalkova T. K. Vydaiushhiisia filolog-skandinavist M. I. Steblin-Kamenskii v blokadnom Leningrade // Sankt-Peterburg i strany Severnoi Evropy. St. Petersburg, 2017. P. 31.

5 Baryshnikov V.N. Igor' Pavlovich Shaskol'skii - osnovatel' leningradskoi shkoly istorikov-skandinavistov // Trudy kafedry istorii Novogo i noveishego vremeni. No. 9. St. Petersburg, 2012. P. 136.

${ }^{6}$ See, for example: Istoriia Datskaia, sochinennaia gospodinom Golbergom, kotoruiu sokratil i pripisal k nei svoi primechaniia artillerii kapitan Jakov Kozel'skii. St. Petersburg, Ch. 1-2. 1765-1766; Zapiski Usta Ulia datskogo poslannika pri Petre Velikom (1709-1711) izvlek iz Kopengagenskogo Gosudarstvennogo Arhiva i perevel s datskogo Ju. N. Shherbachev. Moscow, 1899; Gedelund L. N. Istoriia Danii. St. Petersburg, Moscow, 1907.

${ }^{7}$ Lichnoe delo Vozgrina Valeriia Evgenevicha // Arkhiv instituta istorii RAN v Sankt-Peterburge. Op.2. D. 471. P. 14.

8 Vozgrin V.E.: 1) Datsko-golshtinskoe sopernichestvo pri russkom dvore vesnoi 1714 goda // Social'no-politicheskaia istoriia SSSR. Moscow, 1974. P. 191; 2) Zakliuchenie russko-datskogo nastupatel'nogo soiuznogo dogovora 1709 goda // Istoricheskie zapiski. Vol.93. Moscow, 1975 P. 309; 3) Travental'skii dogovor 1700 g. i ego znachenie v istorii Severnoi voiny // Skandinavskii sbornik. Kn. XX. Tallinn, 1975. P. 81.

9 Vozgrin V.E.: 1) Dokumenty Datskogo Gosudarstvennogo arkhiva po istorii Rossii // Sovetskie arkhivy. 1973. No. 5. P. 102; 2) Kniga ob Alandskikh ostrovakh // Istoriia SSSR. 1973. No. 1. P. 200. 
In addition, it is noteworthy that in the late 1960s and 1970s, the first real opportunities of scientific communication with foreign historians from the Nordic countries were opening up ${ }^{10}$. V.E. Vozgrin took active part in this creative interaction by participating in regular international conferences ${ }^{11}$. Moreover, to V. E. Vozgrin, the development of heated discussions was an important component of the meetings with scholars of Scandinavian countries. As he stressed, it was "indispensible as a number of previously expressed ideas was discussed in a new light, criticized or clarified by the speakers" 12 . In general, a debatable and often very critical approach to the long-established ideas was characteristic for V.E. Vozgrin's entire scholarly life.

It is obvious that Valery Evgenyevich's talent was noticed in the Leningrad branch of the Institute of History of the USSR Academy of Sciences. In 1984, he was appointed Senior fellow and then - a leading researcher at the institute. V.E. Vozgrin was one of the few who studied the history of Scandinavian countries and their relations with Russia. He had been working at the Leningrad branch of the Institute of History for 27 years. In 1977, V.E. Vozgrin successfully defended his PhD thesis in history on "Russian-Danish relations in 1697-1714". His supervisor was professor I. P. Shaskolskii who highly assessed his research.

Moreover, it was astonishing that the young researcher after finishing his thesis continued a thorough study of sources and literature on the period of the late $17^{\text {th }}$ and early $18^{\text {th }}$ centuries. As a result, he published a number of very interesting works in the top historical journals of the USSR ${ }^{13}$. In addition, more of his scholarly papers came out abroad $^{14}$. To a large extent, it was as an academic recognition of the historian. The fact that V.E. Vozgrin was invited to join a team of the leading Soviet researchers of Scandinavia to work on a large-scale research project on the history of Denmark was also important for his professional career. It was a very ambitious long-standing project ${ }^{15}$ which was fully implemented only in the $1990 \mathrm{~s}^{16}$.

In general, continuing his research activities, in 1986, V.E. Vozgrin finished his monograph on a fundamental topic: "Russia and European countries during the Northern War (history of diplomatic relations in 1697-1710)"17. In this work, based on the documents from the Soviet and foreign archives, he explored the diplomatic history on the eve of the

${ }_{10}$ Baryshnikov V.N., Daudov A.H. Izuchenie istorii stran Severnoi Evropy v Sankt-Peterburge (XVIII-XXI vv.). P. 172.

11 Vozgrin V.E.: 1) Materialy Sovetsko-finskogo simpoziuma v Leningrade // Leningradskoe otdelenie Instituta istorii AN SSS. Leningrad, 1972. P. 149; 2) Publikatsiia materialov Sovetsko-finskogo simpoziuma po social'no-ekonomicheskoi istorii // Skandinavskii sbornik. Kn. HHII. Tallinn, 1977. P. 249; 3) VI sovetskofinliandskii simpozium // Skandinavskii sbornik. Kn. XXIV. Tallinn, 1979. P. 209.

12 Vozgrin V.E. Publikatsiia materialov Sovetsko-finskogo simpoziuma po social'no-ekonomicheskoi istorii. P. 252.

${ }^{13}$ See, for example: Vozgrin V.E.: 1) Hans Bager. Reformy Petra Velikogo. Obzor issledovanii // Voprosi istorii. 1981. No. 3. P. 157; 2) Petrovskaia epokha v noveishei skandinavskoi istoriografii // Istoriia SSSR. 1981. No.3. P. 206; 3) Sven Oge Kristensen. Istoriia Rossii v XVII v. // Voprosi istorii. 1982. No. 6. P. 165; Bogdanov A.P., Vozgrin V.E. Moskovskoe vosstanie 1682 g. glazami datskogo posla // Voprosi istorii. 1986. No.3. P.78.

14 Vozgrin V.E. Norden i Russisk Historie. Oslo, Gyldendal Akademisk, 1991. P. 324.

15 Baryshnikov V.N. «Skandinavskii sbornik» i osobennosti izucheniia v SSSR istorii stran Severnoi Evropy (1950-1960 gg.) // Sankt-Peterburg i strany Severnoi Evropy. St. Petersburg, 2019. No. 20 (2). P. 177.

16 Istoriia Danii s drevneishego vremeni do nachala XX veka. Moscow, 1998. P. 503.

17 Vozgrin V.E. Rossiia i evropeiskie strany v gody Severnoi voiny (istoriia diplomaticheskikh otnoshenii v 1697-1710 gg.). Leningrad, 1986. 
Great Northern War and put forward new viewpoints for the domestic historiography. In addition, the monograph detailed complex issues of the diplomatic history of this war in the first decade of 1700-1720. On the basis of sources from Russian and foreign archives that were firstly introduced into scholarship, V.E. Vozgrin managed to convincingly present the whole range of problems of diplomacy, foreign policy of Peter's Russia and a number of European countries involved in the orbit of the Northern War. As a result, the historian summed up the centuries-old process of the Baltic question in Russia. Thus, he undoubtedly continued researching the issues to which other outstanding Russian historians of Scandinavia, graduates from the St. Petersburg/Leninrad University, professors G. V. Forsten and I. P. Shaskolskii, had made great contribution ${ }^{18}$. It was no coincidence that the research done by V.E. Vozgrin formed the basis for his doctoral thesis on "Russia and European countries during the Northern War (history of diplomatic relations in 1697-1710)". V. E. Vozgrin brilliantly defended it in December 1988. His opponents were Doctors of Historical Sciences A. I. Kopanev, G. A. Nekrasov and H.E. Palli. V.E. Vozgrin managed to convincingly prove that during the period under consideration there were radical changes not only in Russia's foreign policy, but also in the policy of Sweden and its allies.

It is of interest that V.E. Vozgrin, along with the thorough preparation of his doctorate thesis, undertook another under-researched topic related to the history of the former colony of Denmark - the history of the island of Greenland - as well as a purely ethnographic problem of the history of the Greenland Eskimos. As a result, he published a number of very interesting articles on this topic ${ }^{19}$. Afterwards, in 1984, the monograph "Greenland and Greenlanders" was brought out ${ }^{20}$. This work is unique in terms of its content as it is still the most comprehensive study on the history and ethnography of the world's largest island. The peculiarity of the book lies in the fact that it clearly shows the desire to look at Greenland not only from a traditional perspective of "a geographer", but, first of all, to approach the research question as an ethnographer, historian, political scientist and even an economist. It can be stated that no other research so far has surpassed its comprehensive, interdisciplinary approach to the study of life of the population of Greenland.

An important feature of the work done by V.E. Vozgrin was also the fact that in his description he dramatically changed the entire epoch he studied. The researcher carried out an analysis of the socio-economic situation in Greenland in modern times, particularly, in the period of the 1960-1970s. Moreover, his work sparked an obvious interest as professor Vozgrin actively used innovative methods of comparative analysis. The author apparently sought to draw the most attention to the situation in Greenland at that time. The situation in the recent Danish colony was clearly different from what was happening in most third world countries. According to V.E. Vozgrin, those differences, as a rule, were then "not in favor" of Greenland; they exacerbated the already considerable obstacles on

18 See: Forsten G. V. Baltiiskii vopros v XVI i XVII stoletiiakh (1544-1648). Vol. 1, 2. St. Petersburg, 1893-1894; Shaskol'skij I. P.: 1) Shvedskaia interventsiia v Karelii v nachale XVII veka. Petrozavodsk, 1950; 2) Bor'ba Rusi protiv krestonosnoi agressii na beregakh Baltiki XII-XIII v. Leningrad, 1978; 3) Bor'ba Rusi protiv shvedskoi ekspansii v Karelii. Konets XIII - nachalo XIV v. Petrozavodsk, 1987; 4) Bor'ba Rusi za sokhranenie vykhoda k Baltiiskomu moriu v XIV veke. Leningrad, 1987.

${ }^{19}$ Vozgrin V.E.: 1) Novyi put' Grenlandii // Rabochii klass i sovremennyi mir. 1979. No.4. P.109; 2) Ekonomicheskoe i sotsial'noe razvitie Grenlandii // Mirovaia ekonomika i mezhdunarodnye otnosheniia. 1980. No.3. P. 127; 3) Grenlandtsy // Rasy i narody. Sovremennye etnicheskie i rasovye problemy. 1983. No. 13. P. 216; 4) Grenlandskie normanny // Voprosy istorii. 1989. No. 2. P. 186.

20 Vozgrin V.E. Grenlandiia i grenlandtsy. Moscow, 1984. P.7. 
the way of its development. The researcher linked Greenland's difficulties to the "problem of the united state of Greenland and Denmark" which influenced the issues of production and social and cultural life of Greenlanders ${ }^{21}$.

It is noteworthy that V.E. Vozgrin continued his research activity in that direction, which formed a special sphere of his interests during further creative life. Moreover, the "Greenland studies" were subsequently expanded on a problematic and chronological scale. The scholarly interest of V.E. Vozgrin in the matter was quite understandable. The truth is that the history of Denmark as a colonial empire had not been a subject of special research either national or in international scholarship. Thus, this work proved to be innovative as other authors had previously devoted to this issue only a few notes. They were mentioned in the works concerning the general history of the state, or in articles related to the history of trade, economy, international law, Danish politics, the everyday life of the population of the metropolis and its colonies in various historical epochs. V.E. Vozgrin's research filled the existing niche.

Therefore, professor V.E. Vozgrin had prepared a series of works on Danish and then Swedish colonial issues ${ }^{22}$. With regard to it, the most problematic article is "Models of Denmark's Colonial Policy: Similarities and Differences" published in "Vestnik of St. Petersburg University" in 2010. In the article professor clearly formulated the research question combining it with socio-political and economic considerations ${ }^{23}$. In the course of the study V.E. Vozgrin came to a very original conclusion that the former Danish empire had several models of its colonial policy. In particular, he pointed out that the Danes proclaimed the principle of equality between the local population and representatives of the metropolis in colonies of Estland and Kurland in the $16^{\text {th }}$ century. Thus, "they have gained recognition of the aboriginal people, previously driven to the brink of physical destruction by constant bloody invasions from the South and East" 24 . But the "colored" inhabitants of the Danish colonies outside Europe experienced a different attitude. And even in later period, in $17^{\text {th }}$ and $18^{\text {th }}$ centuries, there was a model based on the exploitation of slave labor in the overseas possessions of the empire. Afterwards, during the $19^{\text {th }}$ century, colonial policies acquired more humane and democratic traits, and at the turn of the century they were replaced by a model of neo-colonialism based on the principle of employment. Finally, at the beginning of the $21^{\text {st }}$ century, the Danes voluntarily parted with $98 \%$ of their territory in order to fulfill the will of the people of Greenland that had been the former colony of the Kingdom. It was "an act unparalleled both in the history of decolonization and in the history of the world as a whole". Therefore, V.E. Vozgrin argued, "it is not difficult to conclude that the Danish models of colonial policy, with the emergence of each new era, followed the spirit of the times, which is their common feature". According to the author, over the past 100 or 120 years, the Danes have twice offered the world novel ways of dealing with colonial problems. In this regard, V.E. Vozgrin put forward a hypothesis

21 Vozgrin V. E. Grenlandiia i grenlandtsy. P. 112.

22 See: Vozgrin V.E.: 1) Modeli kolonial'noi politiki Danii: skhodstva i razlichiia // Vestnik of Saint Petersburg University. History, 2010. No.4. P.53; 2) Datskii put' k dekolonizatsii Grenlandii: Vyzov sovremennoi kolonial'noi ideologii i praktike // Sankt-Peterburg i strany Severnoi Evropy. 2010, no. 11. P.259; 3) Ischeznuvshie ostrova (Skandinavskaia Vest-Indiia) // Sankt-Peterburg i strany Severnoi Evropy. 2012. No.13. P.81; 4) Zakat Datskoi kolonial'noi Imperii // Sankt-Peterburg i strany Severnoi Evropy. 2018. No. 19 (1). P. 72.

${ }^{23}$ Vozgrin V.E. Modeli kolonial'noi politiki Danii: skhodstva i razlichiia. P. 53.

24 Ibid. P. 57. 
that the Danish example could be inspiring and the governments of the former empires could find the strength "to realize that the forced retention of small peoples in the old state framework is becoming not only disrespectable, but also, by and large, unprofitable as a real atavism that has survived to our days from bygone eras of 'land gathering' "25. In our opinion, this statement certainly requires further examination. Some steps in this direction have already been made by his colleagues ${ }^{26}$.

But in general, working at the History Faculty (now the Institute of History) of St. Petersburg State University since 2005, professor V.E. Vozgrin had studied very extensively the problems of colonial expansion of the West countries paying most attention to its Scandinavian variety. As a result, in 2011 he prepared a separate textbook: "The History of the Swedish and Danish Colonial Empires"27. The significance of this work was not inferior to his monograph, and proved to be a unique research, which still has not had any analogues in national historiography.

It should be pointed out that again this work was characterized by professor V.E. Vozgrin's tendency to trace the entire process of the formation and development of the colonial system of the Scandinavian countries in its close connection with the evolution of the political, economic, social and cultural life, from the $14^{\text {th }}$ century to the present day. Furthermore, guided by the comprehensive approach, the scholar managed to reveal an important feature of the Scandinavian colonial strategy. It was often defined, as the researcher convincingly showed, by the foreign policy of the Nordic countries. Indeed, it had a noticeable influence on the whole European life. This trend undoubtedly pointed to the natural link between the North European region and the rest of Western Europe.

In general, Professor V.E. Vozgrin's change over to St. Petersburg State University marked an upsurge in his creativity. During 14 years of work at the Department of Modern and Contemporary History, he published most of his scholarly works. Moreover, the priority areas of his research, which had been formed in the previous period, were fully preserved.

In particular, Professor Vozgrin V.E. continued to actively study historical sources. In this regard, he analyzed certain little-known material related to the history of the Nordic countries and Russian-Scandinavian relation ${ }^{28}$. In addition, as previously, he focused on the history of the Great Northern War as well as on the first quarter of the $18^{\text {th }}$ century as a whole. In 2007, another volume of "Year 1725" was published within the framework of the historical series "The Fatal Years of Russia': A Documentary Chronicle". The series was distinguished by the author's use of a large number of documentary sources accom-

25 Ibid. P. 203.

${ }^{26}$ Chepik V.N. Great Miscalculation of David Cameron // Vestnik of Saint Petersburg University. History. 2018. Vol. 63, iss. 1. P. 303.

${ }_{27}$ Vozgrin V.E. Istoriia shvedskoi i datskoi kolonial'nykh imperii: Uchebnoe posobie. St. Petersburg, 2011.

${ }^{28}$ See, for example: Vozgrin V.E.: 1) Severnaia voina v «Istorii Petra» F. I. Soimonova // Sankt-Peterburg i strany Severnoi Evropy. 2004. No.5. P. 211; 2) Natsional'naia politika v Peterburge 1730-kh gg. v zapiskakh datskogo pastora P. Havena // Sankt-Peterburg i strany Severnoi Evropy. 2007. No. 8. P.399; 3) Voenno-politicheskii konflikt v period prebyvaniia Karla XII v Turtsii (1709-1714) (po neopublikovannym dokumentam) // Problemy voiny i mira v epokhu Novogo i noveishego vremeni. 2008. P. 57; 4) Morskie zhurnaly N. A. Seniavina i F. M. Apraksina kak istochnik po istorii Severnoi voiny // Sankt-Peterburg i strany Severnoi Evropy. 2008. No. 9. P. 206; 5) Hronika Sture (Ekscerpt) // Trudy kafedry istorii Novogo i noveishego vremeni. 2009. No.3. P.274; 6) Srednevekovye litterati i illitterati v skandinavskoi i inykh kul'turakh // Sankt-Peterburg i strany Severnoi Evropy. 2018. No. 19 (1). P. 196. 
panied by unique illustrations. In this edition, V.E. Vozgrin, introduced into scholarship many foreign materials, including correspondence and memoirs of individuals, dispatches of diplomats, articles and notes from foreign newspapers ${ }^{29}$. As a result, this publication has acquired a unique significance for Russian researchers. The publication of sources by professor V.E. Vozgrin went along with the publication of a large number of his articles, which appeared with enviable regularity every year in various journals ${ }^{30}$.

Despite his involvement in academic activity, he did not forget about his teachers even at the end of his life. And in this regard, he managed to reveal his considerable abilities as an organizer. In particular, in 2009, V. E. Vozgrin organized a conference dedicated to the ninetieth anniversary of his teacher Igor Shaskolskii. In the welcome speech at the conference, V.E. Vozgrin with deep respect described the life path of his teacher. "Igor Shaskolskii lived a long life devoted entirely to historical science". He went on to emphasize with great appreciation: "Igor Pavlovich was a warmhearted, kind, sympathetic and invariably benevolent man" 31 . The very range of invited participants of the conference was determined by the scholarly interests of the historian. The participants noted a special role of the Nordic countries in the history of Russia as well the importance of the relationship between the peoples of the Scandinavian region and our motherland. They outlined the prospects for further researches on the topic. It was decided to include in the conference compendium the article of I. P. Shaskolskii which had already been published earlier in 1998 but was supplemented and finalized by the time of the conference started by his former students Professor V.E. Vozgrin and candidate of historical sciences T. A. Schrader. They coped successfully with this difficult and very delicate task ${ }^{32}$. Thus, the tradition of continuity in the research process was maintained, and the tribute to the memory of I. P. Shaskolskii was paid to by his followers.

Acknowledging his teacher, V.E. Vozgrin also delivered a separate report. It dealt with foreign policy issues. Despite the fact that the work was mainly devoted to the southern direction of the Russian foreign policy, the author on the basis of archival and other sources for the first time in historiography revealed the purposes of multilateral negotiations on the issues related to the major events of the Great Northern War between the representatives of Russia, Sweden, Crimea Turkey and Turkey ${ }^{33}$. In general, the symposium of the conference "Problems of the history of Russia and the Nordic countries: from the Middle Ages to the present day (to the $90^{\text {th }}$ anniversary of I. P. Shaskolskii)" became a solid contribution to the development of historical science and to the study of relations between Northern Europe and Russia.

29 Vozgrin V.E. God 1725. «Rokovye gody Rossii»: Dokumental'naia khronika. St. Petersburg, 2007.

30 See: Vozgrin V.E.: 1) Problema genotsida v rossiiskoi i skandinavskoi istoriografii Severnoi voiny // Sankt-Peterburg i strany Severnoi Evropy. 2005. No.6. P.214; 2) Politicheskie otnosheniia Karla XII s krymskimi khanami i turetskim sul'tanom v gody Severnoi voiny // Skandinavskie chteniia. St. Petersburg, 2010. P. 87; 3) Dela i dni petrovskogo vitse-kanslera P.P.Shafirova // Trudy kafedry istorii Novogo i noveishego vremeni. 2015. No. 14. P. 223; Vozgrin V.E., Plenkov O. Y. A. D. Men'shikov - otvazhnyi pioner rossiiskoi korruptsii Novogo vremeni // Klio. 2016. No. 6 (114). P. 170.

31 Problemy istorii Rossii i stran Severnoi Evropy: ot Srednikh vekov do nashikh dnei (k 90-letiiu so dnia rozhdeniia I. P. Shaskol'skogo) / sost. V.E. Vozgrin. St. Petersburg., 2009.

32 Shaskol'skij I. P., Vozgrin V.E., Shrader T. A. Gramoty kniazia Vasiliia III sborshhikam dani v Lopskoi zemle // Problemy istorii Rossii i stran Severnoi Evropy: ot Srednikh vekov do nashikh dnei. St. Petersburg, 2009. P. 41.

${ }^{33}$ Vozgrin V.E. Iuzhnyi front rossiiskoi vneshnei politiki nakanune i posle Poltavy // Problemy istorii Rossii i stran Severnoi Evropy: ot Srednikh vekov do nashikh dnei. P. 80. 
Professor V.E. Vozgrin was actively engaged in joint research conducted by his colleagues at the Department of Modern and Contemporary History ${ }^{34}$. He was one of the co-authors in the monograph "From the History of Constitutional Construction in Western Europe in the Modern and Contemporary periods of time" 35 . The book explored the peculiarities of constitutional development in Western Europe in the $19^{\text {th }}$ and $21^{\text {st }}$ centuries. He was also a co-author in the fundamental work "From Nation States to a United Europe: The Problems of European Integration in the $19^{\text {th }}$ and $21^{\text {st }}$ Centuries" which researched the peculiarities of European integration in the $19^{\text {th }}$ and $21^{\text {st }}$ centuries ${ }^{36}$. For example, in the section "The Origins and Ideas of Integration, and its first incarnation in Northern Europe", V.E. Vozgrin examined the stages that the Nordic countries passed. His analysis of the peculiarities of the manifestation of Scandinavianism in the period of Modern time is of particular interest. As the author rightly noted, it has become to a large extent a form of combating the external threat, which "requires solidarity and sacrifice of self-interest in the name of helping neighbors". Moreover, according to professor V.E. Vozgrin, "northern integration is more democratic, which was expressed in greater attention paid by governments to the opinion of the people". However, this did not exclude other certain driving factors from the history of Scandinavianism, which were considered in every detail in the monograph of Vozgrin ${ }^{37}$.

Undoubtedly, the general interpretation of the term "Scandinavianism" is also of great interest in the section prepared by V.E. Vozgrin ${ }^{38}$. Those observations were the result of a comprehensive study as the historian had repeatedly addressed various aspects of the Baltic problem ${ }^{39}$. With regard to this, the attempt to answer the question of, let us say, why Poland had never become a real Baltic Power, and the "Scandinavian world" did not accept it, was innovative in many respects. Professor V. E. Vozgrin convincingly argues that as early as the $17^{\text {th }}$ and $18^{\text {th }}$ centuries Poland still had every chance of becoming one of the major maritime powers in the Baltic region but this did not happen, according to the researcher, primarily because of the ideology (sarmatism) that was then professed by the

34 See, for example: Baryshnikov V.N., Vozgrin V.E. Rossiia i Germaniia glazami molodykh istorikov // Vestnik of Saint Petersburg University. History. 2014. Iss.1. P.202; Vozgrin V.E., Arzamastseva E. Problemy evropeiskoi integratsii v Novoe i noveishee vremia v otnosheniiakh Rossii i stran Severnoi Evropy (vzgliad istorikov) // Vestnik of Saint Petersburg University. History. 2015, iss.2. P. 189; Vozgrin V.E., Baryshnikov V.N. U istokov sovremennoi rossiiskoi "nordistiki”: Professor A. S. Kan i istoriia stran Severnoi Evropy // Klio. 2015. No. 10 (106). P.227; Vozgrin V.E., Kuznetsova Y. I., Baryshnikov V. N., Adamova N. E., Borisenko V.N. Russian Observations of European Experience in Agricultural Development in 1840s (based on the printed output of the Imperial Agricultural Societies of Russia) // Bylye gody. 2016. No.40 (2). P. 412; Vozgrin V.E., Petrova A. A., Ushakov V. A. Dreams about the Black Sea // Vestnik of Saint Petersburg University. History. 2018. Vol.63, iss. 4. P. 1317.

35 Iz istorii konstitutsionnogo stroitel'stva v Zapadnoi Evrope v Novoe i noveishee vremia / pod red. A. V.Smolina. St. Petersburg, 2014.

${ }^{36}$ Ot natsional'nykh gosudarstv $\mathrm{k}$ edinoi Evrope: problemy evropeiskoi integratsii v XIX-XXI vv. / pod red. A. V.Smolina. St. Petersburg, 2016.

37 Ibid. P. 118.

38 Ibid. P. 58.

39 Vozgrin V.E.: 1) Skandinavizm: pervaia popytka integratsii evropeiskikh narodov // Vestnik of Saint Petersburg University. History. 2015. No. 3. P. 54; 2) Skandinavistika v stenakh starogo LOII // "Moia special'nost' - Drevniaia Rus”' Sbornik k 100-letiiu so dnia rozhdeniia I. P. Shaskol'skogo. St. Petersburg. 2018. P. 17; 3) Pochemu Rech' Pospolitaia ne stala (velikoi) Baltiiskoi derzhavoi? // Sankt-Peterburg i strany Severnoi Evropy. 2016. No. 17 (1). P. 61. 
leaders of that state ${ }^{40}$. In our opinion this very original viewpoint, of course, still requires a careful consideration.

On the whole, the critical approach to sources as well as to the creative heritage of its predecessors continued to be a hallmark of the research activities of the outstanding scholar. It was not surprising, therefore, that professor Vozgrin not only had a considerable number of original versions of certain events in history, but was also critically assessed by his colleagues, both from Russia and abroad. Nevertheless, he did not hesitate to expressing his ideas openly and vigorously during academic discussion ${ }^{41}$. The researcher's polemical gift was particularly striking at regular international conferences. In the last years of his life, he had been active in speaking out in a wide variety of scientific forums on the history of the Scandinavian countries and Finland. These were, first of all, conferences "St. Petersburg and the Nordic countries" where he, in fact, became one of their co-organizers ${ }^{42}$. In addition, since 2010, V.E. Vozgrin had become a very active participant in the large international scientific forum "Russia and the Nordic Countries" which had already been held for more than five years in Helsinki. This international conference was run annually by the Chair of Modern and Contemporary History with the organizational support of the Russian Centre for Science and Culture in Finland. Traditionally, the most famous historians not only from Russia and the Nordic countries, but also from Germany, Poland and the Baltics were invited there ${ }^{43}$.

Habitually, professor Vozgrin paid special attention to the views of Danish historians. Indeed, during his creative life Valery Evgenyevich had done a lot of work exploring Danish historiography. Moreover, the analysis of historiographical problems was characteristic of all his works and concerned not only the history of Denmark but also the history of Russia, in which the Danish researchers were also engaged. As a result of many years of creative activity, professor Vozgrin wrote a considerable number of historiographical works on the subject ${ }^{44}$.

40 Vozgrin V.E. Pochemu Rech' Pospolitaia ne stala (velikoj) Baltiiskoi derzhavoi? P. 66.

${ }^{41}$ See: Vozgrin V.E. Rets. na: Tilman Plath. Zwischen Schonung und Menscheniagden. Die Arbeitseinsatzpolitik in den Baltischen Generalbezirken des Reichskommissariars Ostland 1941-1944. Essen, 2012. P. 502 // Trudy kafedry istorii Novogo i noveishego vremeni. 2013. No.11. P. 225; Vozgrin V.E.: 1) Baltiiskii mir - obshhestvo, natsional'nye kul'tury i torgovlia ot epokhi vikingov do Evrosoiuza (rets. na knigu: Michael North. Geschichte der Ostsee: Handel und Kulturen. München: Verlag C. H. Beck, 2011. 448 S.) // Vestnik of Saint Petersburg University. History. 2014. Iss. 1. P. 191;2) Istoriia Pribaltiki v noveishem osveshhenii // Trudy kafedry istorii Novogo i noveishego vremeni. 2018. No. 18 (2). P.286; Vozgrin V.E., Petrova A.A., Ushakov V.A. Dreams about the Black Sea. P.1317; Vozgrin V.E., Teriukov A.I. Eshhe raz o naznachenii Ivangoroda // Vestnik of Saint Petersburg University. History. 2019. Vol.64, iss. 1. P.311; Vozgrin V. E. Novoe plat'e normanizma // Sankt-Peterburg i strany Severnoi Evropy. 2019. No. 21 (1). P. 225.

42 See: Baryshnikov V.N., Krotov P. A. XIX Nauchnaia konferentsiia "Sankt-Peterburg i strany Severnoi Evropy” (Sankt-Peterburg, 25-26 aprelia 2017 g.) // Vestnik RFFI. Gumanitarnye i obshchestvennye nauki. 2017. No.3. P. 166-169; Baryshnikov V.N., Vozgrin V.E., Kozlov N.O. XXI Mezhdunarodnaia nauchnaia konferentsiia "Sankt-Peterburg i strany Severnoi Evropy" (Sankt-Peterburg, 3-4 aprelia 2019 g.) // Vestnik RFFI. Gumanitarnye i obshchestvennye nauki. 2019. No. 2. P. 187-191.

43 See: Konferentsii, provedennye kafedroi istorii Novogo i noveishego vremeni (aprel' - sentiabr' 2012 g.) // Trudy kafedry istorii Novogo i noveishego vremeni. 2012. No. 9. P. 199-218; Nauchnye konferentsii, provedennye kafedroi istorii Novogo i noveishego vremeni (aprel' - sentiabr' 2013 g.) // Trudy kafedry istorii Novogo i noveishego vremeni. 2013. No. 11. P.239-244; Nauchnye konferentsii, provedennye kafedroi istorii Novogo i noveishego vremeni (aprel' — sentiabr' 2014 g.) // Trudy kafedry istorii Novogo i noveishego vremeni. 2014. No. 13. P.251-260.

44 Vozgrin V.E. 1) Sovremennaia datskaia istoriografiia o Novoi istorii Rossii // Mezhdunarodnye otnosheniia v Novoe i Noveishee vremia. Materialy mezhdunarodnoi nauchnoi konferentsii, posviashhennoi 
In particular, one of them is devoted to Danish historians who studied Russia, professors of the University of Copenhagen Knud Rasmussen and Hans Bagger. The study of their work, little known in Russia, was extremely important for Russian historians. Both Danish scholars were part of the elite of foreign historiographical Russian studies. Being the authors of dozens of monographs, they enjoyed fame in Russia. Their works were printed in the Russian language in a large number of copies. Therefore, it was no coincidence that professor Vozgrin elaborated in review on the lives and work of those two "remarkable scholars and extremely amiable people for communication" ${ }^{4}$.

The critical analysis of the modern Danish historiography of the Cold War by professor Vozgrin deserves special attention ${ }^{46}$. Valery Evgenyevich describes historiographical tradition of this phenomenon in the Scandinavian countries since the end of the Cold War. According to this tradition, as the researcher states, European low-ranking countries embroiled in a conflict between two superpowers, had to solve "the problem of choosing an ally and a patron" ${ }^{37}$. As V.E. Vozgrin noted, many well-known works of historians from the Scandinavian countries, including Denmark, were mainly devoted to this problem.

In particular, V.E. Vozgrin agrees with the opinion of professor of the University of South Denmark Bent Jensen, on the position of Denmark and its role in NATO in the 1980 s, i.e., when the decision was made on the so-called zero variant expressed by the author in his monograph "Wolves, sheep and shepherds - the Cold War in Denmark 1945-1991"48. But he openly disagreed with a number of statements of the Danish historian concerning the nature of the Cold War. Expressing his dissent, V. E. Vozgrin very reasonably pointed out that $\mathrm{B}$. Jensen was clearly wrong in his search for the origins of the Cold War, which he saw "in the revolutionary break of the Bolsheviks with the fundamental Western values and in their absolute denial of the U.S.-European models of life and their economic foundation". Having entered into a discussion with the Danish historian, V.E. Vozgrin clearly drew attention to the shortcomings of his research. He believed that Jensen's "conclusions are not always supported by specific sources, the evidence is sometimes based on his logical conclusion, but it is a questionable method in historiography" 49 . Thus, V.E. Vozgrin took it for granted that the historical approach to the study should be based on the verified documentary base. It was one of the fundamental principles of his scholarly work. It was the approach that he used in all his researches during his long life.

As a result, due to many years of thoughtful research activity, the last book of V.E. Vozgrin called "Chroniclers and Historians of Denmark: From the Middle Ages to the Present day" was published in $2019^{50}$. In this monograph, the author attempted to examine the whole history of "Danish historiography from runic petroglyphs to modern

pamiati professora K. B. Vinogradova St. Petersburg, 2005. P. 63-68; 2) Istoriograficheskaia drama - datskie istoriki do i posle natsional'noi katastrofy 1864 g. // Sankt-Peterburg i strany Severnoi Evropy. 2009. No. 10. P. 236. 3) Datskie istoriki XVII-XVIII vv.: nachalo puti k natsional'noi pozitivistskoi istoriografii // SanktPeterburg i strany Severnoi Evropy. 2011. No.12. P.237; 4) Sovremennaia datskaia istoriografiia kholodnoi voiny // Trudy kafedry Novogo i noveishego vremeni, 2016. No. 16 (1). P. 299.

45 Vozgrin V.E. Knud Rasmussen i Hans Bagger - datskie istoriki Rossii // Trudy kafedry istorii Novogo i noveishego vremeni. 2016. No. 16 (2). P. 205.

46 Vozgrin V.E. Sovremennaia datskaia istoriografiia kholodnoi voiny. P. 299.

47 Ibid. P. 300.

48 Jensen B. Ulve, får og vogtere - Den Kolde Krig i Danmark 1945-1991. Bd. I-II. København, 2014.

49 Vozgrin V.E. Sovremennaia datskaia istoriografiia kholodnoi voiny. P. 303.

50 Vozgrin V.E. Letopistsy i istoriki Danii: evoliutsiia natsional'noi istoriografii ot Srednevekov'ia do sovremennosti. St. Petersburg, 2019. P. 5. 
works". Moreover, Professor V.E. Vozgrin sought to analyze all the historical texts used in the study taking into account the influence of cultural traditions, the political environment and changing models of life and historiography of Europe.

In his latest research the author also rightly draws readers' attention to the fact that despite the small territory and relatively small population, Denmark has in fact been a bearer of a rich cultural heritage and historiographical traditions. Professor V.E. Vozgrin again challenges a popular view that in the Middle Ages there were no historians or historical science. In his work he convincingly proves that historians were known in the Middle Ages. In his opinion, in Denmark "there were many historians, and they had a lot of readers". He goes on to say that they were "more precisely, listeners, because Latin was unknown as a language to most population of the North" 51 .

It is significant, however, that professor V.E. Vozgrin was quite self-critical about his work, noting its weakness. According to him, it was impossible to "embrace the immensity". He meant that there had been a rapid increase in literature of recent decades, partly, as a result of emergence of numerous amateur historians. Among the tasks set in his monograph, the following can clearly be distinguished: 1 ) to find out who a medieval historian was and all his followers up to present time; 2) to examine what the theoretical and methodological principles of historical cognition inherent in each school and every direction of historical thought were? 3) to analyze the source base of research in order to identify the history of the discovery and introduction of previously unknown sources; 4) to analyze the conditions in which chroniclers and historians worked in monasteries, universities and academies; 5) to explore what the goals of creative activity and readership of Danish historians were and what legacy they left to their descendants for further development of science? 6) to establish what role this sum of knowledge, this broad panorama of the past, played for the formation of man of present time and modern civilization? ${ }^{52}$ We can conclude that with these tasks, professor Vozgrin, undoubtedly, coped successfully.

Indeed, the author focused on the evolution of Danish historiography which developed under the influence of the aspect of ethnic identity of the Danes. V. E. Vozgrin stated that historical science partly contributed to the ethnic identity of the Danes. He highlighted common features in the ideology of intellectuals who were divided by centuries. First of all, he named "feelings for the homeland, that is devotion to the motherland". The author noted that gradually, when Denmark turned into a small state, the position of historians changed to national-patriotic. In his opinion, with the spread of positivism and then modernism in the late $19^{\text {th }}$ century, the situation began to change in Danish historiography. The discipline was enriched by the history of material culture. Assessing rich historical experience of Denmark, V.E. Vozgrin described it "a small country with a great history" 53 .

In the introduction to the monograph, V.E. Vozgrin expresses gratitude: firstly, to his wife, the researcher Viena-Tuuli Vasara "for her tireless patience and help in writing this book, starting from helping to deliver literature from foreign libraries and finishing with her care during a serious illness that befell the author in the midst of writing his manuscript"; then - to his sons Valentin and Cyril - for their "love and patience which allowed him to go on working on the book not paying attention to the illness". After that he thanks professor Bent Jensen of the University of South Denmark, who had reviewed part

51 Vozgrin V. E. Letopistsy i istoriki Danii... P.7.

52 Ibid. P. 8.

${ }^{53}$ Ibid. P. 705. 
of the text long before work on it was finished. Finally, he acknowledges his colleagues in the Department of Modern and Contemporary History of the Institute of History of St. Petersburg State University. They "deserve a warm gratitude". V.E. Vozgrin wrote: "Thanks to their care I, being bedridden, could work on the manuscript without anxiety concerning my lecture courses at the university. They read them substituting me with no regard for their personal time" 54 .

Indeed, after a severe and prolonged illness Valerii Evgenyevich passed away in January 2020. He left behind a rich creative heritage. His works were published not only in Russia, but also in all Scandinavian countries, Ukraine, Germany, Italy, Turkey, Spain and Estonia. Until the last days of his life V. E. Vozgrin continued to research problems of the cultural, economic, political history of the Scandinavian countries; the military and political history of Russia. He is the author of 220 scholarly papers, including more than a dozen monographs and textbooks. The research base established by professor Vozgrin for studying the history of Scandinavian countries has laid a solid foundation for his students and for further development of the scientific school to whose formation V. Vozgrin made a considerable contribution.

\section{References}

Baryshnikov V.N., Vozgrin V.E. Russia and Germany through the Eyes of Starting Historians. Vestnik of Saint Petersburg University. History, 2014, iss. 1, pp. 202-203. (In Russian)

Baryshnikov V.N., Vozgrin V.E., Kozlov N. O. XXI Mezhdunarodnaia nauchnaia konferentsiia "SanktPeterburg i strany Severnoi Evropy" (Sankt-Peterburg, 3-4 aprelia 2019 g.). Vestnik RFFI. Gumanitarnye i obshchestvennye nauki, 2019, no. 2, pp. 187-191. (In Russian)

Baryshnikov V.N., Krotov P. A. XIX Nauchnaia konferentsiia "Sankt-Peterburg i strany Severnoi Evropy" (St. Petersburg, 25-26 aprelia 2017 g.). Vestnik RFFI. Gumanitarnye i obshchestvennye nauki, 2017, no. 3, pp. 166-169. (In Russian)

Baryshnikov V.N., Daudov A.H. Exploring the History of the Nordic Countries in St. Petersburg $\left(18^{\text {th }}\right.$ and $19^{\text {th }}$ Centuries). Trudy kafedry istorii Novogo i noveishego vremeni, 2013, no. 11, pp. 172-190. (In Russian)

Baryshnikov V.N. Igor Shaskolskii is the Founder of the Leningrad School of Scandinavian Historians. Trudy kafedry istorii Novogo i noveishego vremeni, 2012, no. 9, pp. 136-148. (In Russian)

Baryshnikov V.N. "Scandinavian Collection" and Features of Studying the History of the Nordic Countries in the USSR (1950-1960). Sankt-Peterburg i strany Severnoi Evropy, 2019, no. 20 (2), pp. 177-190. (In Russian)

Bogdanov A.P., Vozgrin V.E. Moscow Uprising of 1682 Through the Eyes of the Danish Ambassador. Voprosy istorii, 1986, no. 3, pp.78-91. (In Russian)

Chepik V.N. Great Miscalculation of David Cameron. Vestnik of Saint Petersburg University. History, 2018, vol. 63, iss. 1, pp. 301-310.

Forsten G. V. The Baltic Question in the $16^{\text {th }}$ and $17^{\text {th }}$ Centuries (1544-1648). St. Petersburg, Tip. V. S. Balasheva i Ko Publ., 1893-1894, vol. 1, 2. (In Russian)

Ganelin R.Sh., Vozgrin V.E. The history of the Crimean Tatars: Essays of the Ethnic History of the Indigenous People of Crimea in Four Volumes. Trudy kafedry istorii Novogo i noveishego vremeni. 2014, no. 12, pp. 252-253. (In Russian)

Gedelund L. N. History of Denmark. St. Petersburg, Moscow, M. O. Vol'f Publ., 1907, 271 p. (In Russian)

Jensen B. Ulve, får og vogtere - Den Kolde Krig i Danmark 1945-1991. Bd. I-II. København, Gyldendal Publ., 2014, $797+709$ p.

Mihalkova T.K. Outstanding Philologist-Scandinavian M.I.Steblin-Kamensky in Besieged Leningrad. Sankt-Peterburg i strany Severnoi Evropy, 2017, no. 17 (1), pp. 31-38. (In Russian)

54 Ibid. P. 13. 
Shaskol'skii I.P. Russia's Struggle to Maintain Access to the Baltic Sea in the $14^{\text {th }}$ Century. Leningrad, Nauka Publ., 1987, 176 p. (In Russian)

Shaskol'skii I. P. The Struggle of Russia Against the Crusader Aggression on the Shores of the Baltic $12^{\text {th }}$ and $13^{\text {th }}$ century. Leningrad, Nauka Publ., 1978, 245 p. (In Russian)

Shaskol'skii I.P. Russia's Struggle Against Swedish Expansion in Karelia. Late $13^{\text {th }}$ to Early $14^{\text {th }}$ centuries. Petrozavodsk, Karelia Publ., 1987, 146 p. (In Russian)

Shaskol'skii I. P. Swedish Intervention in Karelia in the Early $17^{\text {th }}$ century. Petrozavodsk, Gos. Izdatelstvo Karelo-Fin. SSR, 1950, 168 p. (In Russian)

Vozgrin V.E., Arzamasceva E. Problems of European Integration in the Modern and Contemporary History of Relations Between Russia and the Nordic Countries (view of historians). Vestnik of Saint Petersburg University. History, 2015, iss. 2, pp. 189-192. (In Russian)

Vozgrin V.E., Baryshnikov V.N. At the Origins of Modern Russian "Nordicism”: Professor A.S. Kahn and the History of the Nordic Countries. Klio, 2015, no. 10 (106), pp.227-231. (In Russian)

Vozgrin V.E. The Baltic World - Society, National Cultures and Trade from the Viking Era to the European Union (Book Review: Michael North. Geschichte der Ostsee: Handel und Kulturen. München: Verlag C. H. Beck, 2011. 448 S.). Vestnik of Saint Petersburg University. History, 2014, iss. 1, pp. 191-193. (In Russian)

Vozgrin V.E. Danish Historians of the $17^{\text {th }}-18^{\text {th }}$ Centuries: The Beginning of the Path to National Positivist Historiography. Sankt-Peterburg i strany Severnoi Evropy, 2011, no. 12, pp. 237-251. (In Russian)

Vozgrin V.E. The Danish Path to Greenland's Decolonization: A Challenge to Modern Colonial Ideology and Practice. Sankt-Peterburg i strany Severnoj Evropy, 2010, no. 11, pp. 259-275. (In Russian)

Vozgrin V.E. The Affairs and Lifetime of Peter's Vice-Chancellor P. P. Shafirov. Trudy kafedry istorii Novogo i noveishego vremeni, 2015, no. 14, pp. 223-229. (In Russian)

Vozgrin V.E. Documents of the Danish State Archives on the History of Russia. Sovetskie arhivy, 1973, no. 5, pp. 102-103. (In Russian)

Vozgrin V.E. Year 1725. “The Rocky Years of Russia”: Documentary Chronicle. St. Petersburg, Lik Publ., 2007, 264 p. (In Russian)

Vozgrin V.E. Greenland and Greenlanders. Moscow, Mysl' Publ., 1984, 157 p. (In Russian)

Vozgrin V.E. Greenland Normans. Voprosy istorii, 1989, no. 2, 186 p. (In Russian)

Vozgrin V.E. Hans Bagher. Reforms of Peter the Great. Research review. Voprosy istorii, 1981, no. 3, pp. 157159. (In Russian)

Vozgrin V.E. Sture Chronicle (Exserpt). Trudy kafedry istorii Novogo i noveishego vremeni, 2009, no.3, pp. 274-303. (In Russian)

Vozgrin V.E. Historiographical Drama - Danish Historians Before and After the National Catastrophe of 1864. Sankt-Peterburg i strany Severnoi Evropy, 2009, no. 10, pp. 236-251. (In Russian)

Vozgrin V.E. The History of the Baltics: The Latest Assessments. Trudy kafedry istorii Novogo i noveishego vremeni, 2018, no. 18 (2), pp. 286-301. (In Russian)

Vozgrin V.E. History of the Swedish and Danish Colonial Empires: A Textbook. St. Petersburg, St. Peterburg University Press, 2011, 262 p. (In Russian)

Vozgrin V.E. Disappeared Islands (Scandinavian West Indies). Sankt-Peterburg i strany Severnoi Evropy, 2012, no. 13, pp. 81-109. (In Russian)

Vozgrin V.E. Book About the Aland Islands. Istoriia SSSR, 1973, no. 1, pp. 200-201. (In Russian)

Vozgrin V.E. Knood Rasmussen and Hans Bagger - Danish Historians of Russia. Trudy kafedry istorii Novogo i noveishego vremeni, 2016, no. 16 (2), pp. 205-219. (In Russian)

Vozgrin V.E., Kuznetsova Y.I., Baryshnikov V.N., Adamova N.E., Borisenko V.N. Russian Observations of European Experience in Agricultural Development in 1840s (Based on the Printed Output of the Imperial Agricultural Societies of Russia). Bylye gody. 2016, no. 40 (2), pp.412-419. (In Russian)

Vozgrin V.E. Chroniclers and Historians of Denmark: The Evolution of National Historiography from the Middle Ages to the Present. St. Petersburg, Kriga Publ., 2019, 816 p. (In Russian)

Vozgrin V.E. Models of Danish Colonial Policy: Similarities and Differences. Vestnik of Saint Petersburg University. History, 2010, no. 4, pp. 53-60. (In Russian)

Vozgrin V.E. Marine Magazines N. A. Senyavin and F. M. Apraxin as a Source on the History of the Northern War. Sankt-Peterburg i strany Severnoi Evropy, 2008, no. 9, pp. 206-215. (In Russian)

Vozgrin V.E. New Normanism Dress. Sankt-Peterburg i strany Severnoi Evropy, 2019, no. 21 (1), pp. $225-$ 232. (In Russian) 
Vozgrin V.E. Norden i Russisk Historie. Oslo, Gyldendal Akademik Publ., 1991, 324 p.

Vozgrin V.E. The Petrov Era in the Latest Scandinavian Historiography. Istoriia SSSR, 1981, no. 3, pp. 206209. (In Russian)

Vozgrin V.E., Petrova A. A., Ushakov V. A. Dreams About the Black Sea. Vestnik of Saint Petersburg University. History, 2018, vol. 63, iss. 4, pp. 1317-1328. (In Russian)

Vozgrin V.E., Plenkov O. Y. A. D. Menshikov - a Brave Pioneer of Russian Corruption of the New Age. Klio, 2016, no. 6 (114). P. 170-175. (In Russian)

Vozgrin V.E. Why did the Commonwealth not Become a (Great) Baltic Power? Sankt-Peterburg i strany Severnoi Evropy, 2016, no. 17 (1), pp.61-81. (In Russian)

Vozgrin V.E. The Problem of Genocide in The Russian and Scandinavian Historiography of the Northern War. Sankt-Peterburg i strany Severnoi Evropy, 2005, no. 6, pp. 214-230. (In Russian)

Vozgrin V.E. Russia and European Countries During the Northern War (history of diplomatic relations in 1697-1710). Leningrad, Nauka Publ., 1986, 296 p. (In Russian)

Vozgrin V.E. The Northern War in "Peter's Stories" by F.I.Soimonov. Sankt-Peterburg i strany Severnoi Evropy, 2004, no. 5, pp. 211-230. (In Russian)

Vozgrin V.E. Scandinavianism: The First Attempt at the Integration of European Peoples. Vestnik of Saint Petersburg University. History, 2015, no. 3, pp. 54-64. (In Russian)

Vozgrin V.E. Modern Danish Historiography of the Cold War. Trudy kafedry Novogo i noveishego vremeni, 2016, no. 16 (1), pp. 299-308. (In Russian)

Vozgrin V.E. Medieval litterati and illitterati in Scandinavian and Other Cultures. Sankt-Peterburg i strany Severnoi Evropy, 2018, no. 19 (1), pp. 196-215. (In Russian)

Vozgrin V.E., Terjukov A. I. Once Again About the Tasks of Ivangorod. Vestnik of Saint Petersburg University. History, 2019, vol. 64, iss. 1, pp. 311-322. (In Russian)

Vozgrin V.E. Rev op.: Tilman Plath. Zwischen Schonung und Menschenjagden. Die Arbeitseinsatzpolitik in den Baltischen Generalbezirken des Reichskommissariars Ostland 1941-1944. Essen: Klartext Verlag, 2012. 502 S. Trudy kafedry istorii Novogo i noveishego vremeni, 2013, no. 11, pp. 225-230.

Vozgrin V.E. The Sunset of the Danish Colonial Empire. Sankt-Peterburg i strany Severnoi Evropy, 2018, no. 19 (1), pp. 72-82. (In Russian)

Статья поступила в редакцию 14 февраля 2020 г.

Рекомендована в печать 8 июня 2020 г.

Received: February 14, 2020

Accepted: June 8, 2020 